\title{
Evaluering van die kwaliteit van verpleegsorg in enkele tehuise vir bejaardes in die Oranje-Vrystaat
}

\author{
PP du Rand en MV Vermaak
}

\section{Opsomming}

'n Ondersoek is onderneem om die kwaliteit van verpleegsorg in enkele tehuise van bejaardes in die OranjeVrystaat te evalueer. Tien tehuise is besoek en 45 bejaardes is geobserveer. Data is met behulp van ' $n$ gestandaardiseerde instrument versamel. Daar is bevind dat noodsaaklike fiesieke behoeftes soos higiëne en voeding die nodige aandag geniet het. Aspekte soos stimulasie, sosialisering, realiteitsoriëntasie, gewoonte-opleidingsprogramme en oefening het egter nie voldoende aandag ontvang nie. Op grond hiervan blyk dit dat daar ' $n$ benadering van bewaarsorg gevolg word in tehuise vir verswakte bejaardes.

\section{Summary}

A study was undertaken to evaluate the quality of nursing care in a number of homes for the aged in the Orange Free State. Ten homes were visited and 45 frail aged patients observed. Data was collected by means of a standardised instrument. Essential physical needs such as hygiene and nutrition were found to receive the necessary attention. However, aspects such as stimulation, socialisation, reality orientation, habit training programmes and exercise did not receive enough attention. In the light of these findings it was concluded that a custodial care approach was followed in these homes.

\section{Inleiding}

Die verswakte bejaardes in tehuise is in 'n kwesbare posisie omdat hul fisieke en psigiese bronne uiters beperk is. Indien hierdie bejaardes nie toereikende sorg ontvang nie, kan hul toestand sodanig verswak dat hospitalisasie noodsaaklik word. Hospitalisasie is baie duur (Glajchen 1989:163) en daar is min bejaardes wat oor die middele of mediese fondse beskik om die volle koste self te dra. Daarbenewens ervaar bejaardes ' $n$ verskuiwing uit hul bekende milieu baie traumaties en die negatiewe gevolge kan lei tot vertraagde herstel, wat tot verlengde hospitalisasie lei. Hoë kwaliteit verpleegsorg in tehuise vir bejaardes is dus noodsaaklik uit ' $n$ ekonomiese sowel as menslike oogpunt. Daar is egter sekere faktore wat ' $n$ nadelige invloed op die kwaliteit van sorg kan uitoefen. Dit is die verpleegkundige se professionele plig om die faktore te identifiseer sodat regstellende stappe, indien nodig, beplan kan word.

\section{Probleemstelling}

Leemtes in die versorging van bejaardes in tehuise.

Verskeie buitelandse skrywers maak melding van die swak sorg wat in tehuise gelewer word (Roberts et al. 1987:34; Wright et al. 1988:813; Allen \& Turner 1991:1172; Cox et al. 1991:6 en Robertson 1991:16).

Aanduidings soos byvoorbeeld dat die sorg wreed en gedepersonaliseerd is (Wells 1980:92) sowel as dat die verpleegpersoneel hul slegs besig hou met klerikale pligte (Armstrong et al. 1985:494) word gemaak.

Die volgende menings van SuidAfrikaanse skrywers dui ook op leemtes in die versorging van bejaardes.

(i) Gebrek aan stimulering sowel as persoonlike belangstelling in die bejaarde (Trichard et al. 1982:627).

(ii) “... to address the present problems of large numbers of elderly patients in old-age homes who have acute and long-term illnesses and receive inadequate clinical assessment and diagnostics" (Glajchen 1989:162).

(iii) Volgens Eckley is standaarde in Suid-Afrikaanse inrigtings van die hoogste ter wêreld, maar terselfdertyd meld hy egter dat daar in die media teen tehuise aantygings gemaak word (Eckley 1989:1). Geen melding word gemaak van die kriteria wat vir beoordeling van die standaard gebruik is nie.

(iv) "the general impression of the quality of initial assessment is one of sketchiness" (Hunt \& Uys 1990 :22).

Uit bogenoemde is dit duidelik dat die kwaliteit van sorg in tehuise vir bejaardes nie na wens is nie.

Redes vir tekortkominge in die kwaliteit van versorging

In die literatuur is verskeie redes vir bogenoemde ontoereikenhede gevind soos dat negatiewe houdings teenoor bejaardes deur verpleegpersoneel in die Westerse samelewing gehandhaaf word (Murray \& Zetner 1985:545; Slabber
1985:14, Seers 1986:51; en Scott et al. 1991:21).

Nog 'n rede vir swak sorg wat ook direk met die verpleegpersoneel verband hou, is hul gebrek aan kennis van bejaardes en die verouderingsproses (Trichard et al. 1982:626-627; Casteldine 1982:19; en Cohn et al. 1990:21).

Redes wat buite die beheer van die verpleegpersoneel val, is volgens York en Calsyn (1977:500) 'n tekort aan kwaliteit en kwantiteit personeel sowe as fisiese fasiliteite. Daar word ook deur Trichard et al. (1982:626-627) melding gemaak van die gebrek aan veral geregistreerde verpleegpersoneel en dat sekere tehuise nie oor middele beskik om meer ernstige fisieke siektes van bejaardes te hanteer nie. Bestuursaspekte kan dus ook ' $n$ invloed op die kwaliteit van sorg hê.

\section{Doelstellings van die studie}

Om :

- die kwaliteit van verpleegsorg in enkele tehuise vir bejaardes in die OVS te bepaal.

- die teenwoordigheid van sekere geïdentifiseerde faktore wat die kwaliteit van sorg kan beinvloed te bepaal, naamlik :

$\Rightarrow$ faktore wat met bestuur verband hou, $\Rightarrow$ faktore wat met die omgewing verband hou,

$\Rightarrow$ houding en kennis van verpleegpersoneel.

In hierdie artikel word slegs die aspekte ten opsigte van die bepaling van die kwaliteit van verpleegsorg aangespreek. Die redes wat ' $n$ invloed op die kwaliteit van verpleegsorg kan hê (bestuursaspekte, houding en kennis van personeel) word in 'n opvolgartikel bespreek.

\section{Metodologie}

Navorsingsontwerp

Die opname metode is gevolg en die navorsing is beskrywend sowel as evaluerend van aard.

\section{Navorsingstegnieke}

Daar is van ' $n$ versikeidenheid navorsingstegnieke gebruik gemaak om data te versamel. 


\section{Literatuurstudie}

Aangesien die navorsingsprobleem soos geblyk het uit die literatuur oor 'n lang tydperk strek, is ' $n$ literatuur oorsig vanaf die vroeë sewentigjare tot en met die vroeë negentigjare verkry.

\section{Rekordoorsig}

Die rekords van die 45 bejaardes is vir die volgende redes nagegaan:

- om inligting vir die profiel van die bejaardes te verkry; en

- om te bepaal of daar ' $n$ beraming van die bejaardes gedoen is.

\section{Waarneming}

Die kwaliteit van verpleegsorg is aan die hand van ' $n$ instrument deur middel van waarneming bepaal.

\section{Vraagstelling}

Deur middel van die voltooiing van ' $n$ vraelys deur al die personeel en ' $n$ onderhoud aan die hand van 'n vraelys met die verpleegkundige in bevel is sekere faktore wat die kwaliteit van verpleegsorg kan beïnvloed, bepaal (word in opvolgartikel bespreek).

\section{Data-}

\section{insamelingsinstrumente}

Evalueringsinstrument om die kwaliteit van verpleegsorg te bepaal

Die instrument van Uys en Hunt (1990) is gebruik aangesien dit klaar opgestel was en volgens Wilson (1989:338) aan die volgende kriteria voldoen het : daar was aanwysings vir die gebruik daarvan, dit was sensitief om veranderlikes te meet en was bekostigbaar. Daar was geen kopiereg op die instrument nie en dit was vryelik by die Suid-Afrikaanse Verpleegstersvereniging beskikbaar.

\section{Geldigheid en betroubaarheid van die Instrument}

Een van die redes waarom die navorser op genoemde instrument besluit het, is dat dit reeds vir geldigheid en betroubaarheid getoets is in ' $n$ steekproef van 12 inrigtings in die OosKaap en Natal (Uys \& Hunt 1990:19-22). Die interwaarnemer betroubaarheid was 0,916 vir die eerste twee afdelings en 0,892 vir die laaste afdeling. Daar is ook getuies van interne konsekwentheid. Inhoudsgeldigheid van die instrument is aanvaar op grond van die inhoudsgeldigheid van die standaarde en kriteria soos deur 'n portuurgroep gevalideer.

'n Loodsstudie van $10 \%$ is uitgevoer. Tydens die loodsstudie het die navorser ondervinding met die respondente, metodologie en instrumente opgedoen wat die betroubaarheid verhoog.

$\mathrm{Na}$ afloop van die loodsstudie is sekere aspekte van die kwaliteitversekeringsinstrument van Uys en Hunt (1990) met een van die opstellers van die instrument uitgeklaar.

Konstrukgeldigheid is gebaseer op die vermoë van die instrument om tussen twee verskillende inrigtings te differensieer. Om die betekenisvolheid van die verskil tussen die inwoners te bereken is die Kruskal-Wallis toets gebruik op die totale tellings van die inwoners. Dit was 38,5 wat betekenisvol op die 0,01 vlak is, met ander woorde daar was ' $n$ betekenisvolle verskil tussen die verskillende inwoners en konstrukgeldigheid kan dus aanvaar word (Uys \& Hunt 1990:20).

\section{Dle profiel van die bejaardes}

Uit die literatuur het dit geblyk dat sekere inligting benodig word om 'n profiel van die bejaardes te verkry. Die doel van die verkryging van hierdie inligting was die belangrikheid van sekere aspekte in die versorging van bejaardes soos byvoorbeeld geneesmiddels.

Vraelys wat voltooi is aan die hand van ' $n$ onderhoud met verpleegkundiges in bevel

Die doel van die vraelys was om sekere bestuursaspekte te bepaal (word in opvolgartikel bespreek).

\section{Vraelys vir al die personeel}

Die doel van hierdie vraelys was om die huidige situasie in Suid-Afrikaanse tehuise ten opsigte van sekere aspekte te bepaal. Die personeel se houding en kennisvlak is ook met behulp van ' $n$ Likert-skaal bepaal en word in die opvolgartikel bespreek.

\section{Steekproef}

Twee steekproewe is gebruik : Eenva van die tehuise $(N=10)$ en een van bejaardes $(\mathrm{N}=45)$.

\section{Steekproefbepallng van die tehuise vir bejaardes}

'n Gestratifiseerde ewekansige steekproef (Uys \& Basson 1983:97) van al die blanke tehuise in die OranjeVrystaat is getrek. Die grootte van die tehuise is vir stratifikasie gebruik en ' $n$ $25 \%$ steekproef van die populasie is getrek uit groot (tehuise met 40 of meer verswakte bejaardes) en klein (tehuise met 10 tot 39 verswate bejaardes) is getrek.

\section{Steekproefbepallng van die bejaardes wat geobserveer is}

'n Nie-ewekansige steekproef is getrek Doelgerigte seleksie is aan die hand van insluitingskriteria gedoen. Die insluitings-kriteria was bedlêend, stoelvas en loop met hulp. Volgens Uys en Basson (1983:100) gaan dit by doelgerigte seleksie ook om die gerief van die navorser. Daar is dus doelbewus gepoog om twee bejaardes gelyktydig in een kamer te observeer.

Dataversameling het oor ' $n$ periode van vier maande plaasgevind en alle data is deur die navorser self ingesamel. In 'n groot tehuis het dit oor twee dae en in ' $n$ klein tehuis oor een dag gestrek.

\section{Leemtes in die navorsing}

Daar is gevind dat 111 onopgeleide verpleeghulpe in die steekproef van tehuise gewerk het en dat hulle $43,8 \%$ van die personeel uitgemaak het. Hierdie werkers speel ' $n$ belangrike rol in die basiese versorging van bejaardes. Hulle is egter nie in die studie betrek nie. Sekere aspekte van die proses van verpleging is moeilik om te evalueer, byvoorbeeld of urienkateters volgens aseptiese tegniek passeer word.

\section{Resultate}

\section{Profiel van bejaardes}

Soos blyk uit die histogram (Figuur1) was die mediese diagnoses wat die meeste voorgekom het kardiovaskulêre toestande, artritis en verwardheid/ demensie. Die diagnoses wat onder "ander" geklassifiseer is, was een bejaare met diabetes mellitus en twee met parkinsonisme. In 'n ondersoek van Wicht et al. (1998:8) was die voorkoms van die lokomotoriese stelsel (voetprobleme en rumatiek) die mees algemene en kardiovaskulêre afwykings die tweede hoogste, naamlik (13\%). Daar is dus ' $n$ ooreenkoms tussen die voorkoms van kardiovaskulêre afwykings en artritis in die twee studies. Die ouderdom van bejaardes het gevarieer tussen 62 jaar en 99 jaar en die gemiddeld was 82,4 jaar.

Dit was interessant dat $10(22,2 \%)$ bejaardes minder as ' $n$ jaar in die tehuis woonagtig was. Die meeste $(51,2 \%)$ was egter tussen een en vyf jaar in die tehuis Een bejaarde was al 13 jaar in die tehuis woonagtig. Aangesien daar voortaan slegs verswakte bejaardes in tehuise opgeneem gaan word (Howes 1989:238) voorsien die navorser dat die tydperk wat ' $n$ bejaarde in ' $n$ tehuis gaan deurbring moontlik korter sal wees. Volgens Pieterse (1990:1-2) sal 'n tehuis slegs die laaste toevlugsoord wees en nie meer ' $n$ blyplek of losieshuis nie.

\section{Geneesmiddels}

Slegs twee $(4,4 \%)$ van die 45 bejaardes het geen middels gebruik nie. Die meeste $26(57,8 \%)$ neem van vyt tot agt middels. Hierdie gegewens is in ooreenstemming met die literatuur (Eliopoulos 1983:65; Wicht 1984:347; en Meiring 1989:60). Daar was 237 voorskrifte wat 'n gemiddeld van 5.3 per bejaarde verteenwoordig. Vir vier $(8,9 \%)$ van die bejaardes was van nege tot 11 middels per persoon voorgeskryf. Hierdie feit is van belang ten opsigte van die werkslading van die verpleeg- 
- ncraromozm

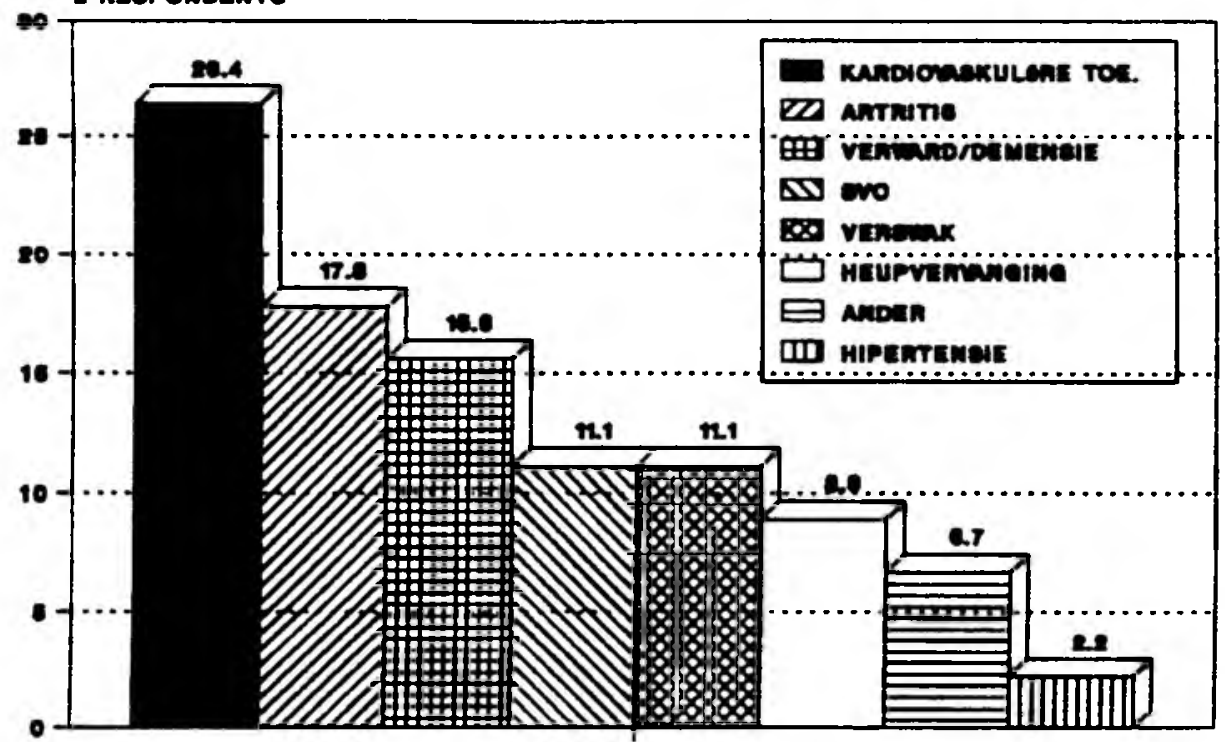

Dinnoer

FIGUUR 1: Mediese diagnoses van bejardes ( $N=45$ )

kundiges in tehuise want volgens Wicht et al. (1989:15) is toesighouding oor die inname van geneesmiddels uiters belangrik. Die navorser het ook waargeneem dat die grootste deel van die verpleegkundige se tyd deur geneesmiddelharitering in beslag geneem word.

Die navorser het elke bejaarde se voorskrif afgeskryt en in samewerking met 'n apteker gekyk vir moontlike interaksies tussen die verskillende middels. Nege-en-twinting moontlike interaksies tussen die verskillende geneesmiddels wat vir 43 bejaardes voorgeskryf is, is geidentifiseer. Hierdie aspek kan die kwaliteit van sorg van ' $n$ bejaarde beinvloed alhoewel dit nie in hierdie studie in ag geneem is nie omdat die instrument nie daarvoor voorsiening maak nie. Die rede daarvoor is dat geneesmiddels deur die geneesheer voorgeskryf word en sy rol nie in die studie ter sprake is nie.

\section{Kwaliteit van verpleegsorg}

Die struktuur

Die struktuur van al die tehuise was oor die algemeen goed en die omgewing buite het goed versorg voorgekom. Al die tehuise het oor eetkamers beskik en slegs twee het nie oor 'n sitkamer beskik nie wat dit baie ongerieflik vir die inwoners maak. In drie van die tehuise was die eetkamertafels nie vir rystoele toeganklik nie. Dit beteken dat pasiënte by die tafel op ' $n$ eetkamerstoel oorgetel moes word. Dit het hulle moeg gemaak, was tydrowend en het die werkslas van die personeel verhoog. Die ongerief wat die pasiënte ervaar het, kon hulle laat besluit het om liewers in die kamer te eet wat negatief op sosialisering kan inwerk.
Nie een tehuis het spesiaal voorsiening vir verwarde inwoners gemaak nie. 'n Veilige plek buite die tehuis, soos ' $n$ boomryke area, om hulle in staat te stel om ook in die buite lug te kom sonder die gevaar dat hulle kan wegdwaal of hulself kan beseer kan baie vir die welsyn van bejaardes beteken. Slegs drie tehuise het daarvoor voorsiening gemaak.

Toiletfasiliteite was ook voldoende maar nie een tehuis se toiletdeure was met ' $n$ spesifieke kleur geïdentifiseer nie sodat die verwarde inwoners nie die toilet kan herken nie. In ses tehuise is die toiletsitplekke nie verhoog nie wat dit veral moeilik maak vir bejaardes met artritis en wat heupvervangings gehad het.

Die ruimte in die kamers van drie tehuise was uiters beperk. Dit gebeur byvoorbeeld wanneer 'n vyfde bejaarde in ' $n$ vierbed ruimte ingedruk word. Om in so ' $\mathrm{n}$ beperkte tuimte te verpleeg is uiters moeilik en dit is ook vir die bejaardes ongerieflik.

Ten opsigte van stoele is die indruk verkry dat 'n stoel in ' $n$ tehuis oor die algemeen net as ' $n$ item van toerusting beskou word. Daar was in geen tehuis verskillende modelle gemakstoele beskikbaar nie en ses tehuise het nie voldoende gemakstoele gehad nie. Alhoewel Wells (1986:13) van mening is
Tabel 1 : Aspekte in die struktuur wat verband hou met situmlasie, oriëntasie en kommunikasie van verswakte bejaardes $(\mathbf{N}=\mathbf{1 0})$

Aspekte met betrekking tot stimulasie, oriëntasie en kommunikasie

Radio is afwisselend aangeskakel

Vertrekke het groot naamborde

Daaglikse koerante is aan inwoners

beskikbaar

Horlosies in slaapkamers

Kalenders in slaapkamers

Inwoners se name op beddens

Inwoners word op individuele wyse aangespreek

Sosiale interaksie tussen pasiënte word deur die personeel gestimuleer Individue mag troeteldiere aanhou

Daaglikse roetine volg normale tye maar laat speling toe vir variasie

Voortdurende raliteitsoriëntasie word met verwarde bejaardes gedoen

'n Program wat hulle in die aande

vermaak word voorsien

'n Geskrewe program is beskikbaar vir Ja Nee

F $\%$ F $\%$

00

10100

110

990

440

660

220

880

440

660

220

880

110

990

330

$7 \quad 70$

00

10100

330

770

00

10

100

die onderrig van kontinensie gewoontes

' $n$ Georganiseerde program van sosiale stimulasie word gevolg 


\section{Tabel 2 : Aangeleenthede waargeneem tydens etenstye van bejaardes wat self eet $(N=33)$}

\begin{tabular}{|c|c|c|c|c|c|}
\hline \multirow{2}{*}{\multicolumn{2}{|c|}{ Aspekte tydens etenstye }} & \multicolumn{2}{|c|}{ Ja } & \multicolumn{2}{|c|}{ Nee } \\
\hline & & $\mathbf{F}$ & $\%$ & $\mathbf{F}$ & $\%$ \\
\hline$\bullet$ & Geskikte eetgerei word gebruik & 30 & 90,9 & 3 & 9,1 \\
\hline$\bullet$ & $\begin{array}{l}\text { Voldoende tyd word geskeduleer om } \\
\text { onafhanklik te eet }\end{array}$ & 29 & 87,8 & 4 & 12,2 \\
\hline - & $\begin{array}{l}\text { Voorsiening word gemaak vir spesiale } \\
\text { dieetbehoeftes }\end{array}$ & 27 & 81,8 & 6 & 18,2 \\
\hline 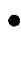 & Die inwoner sit gemaklik & 21 & 63,6 & 12 & 36,4 \\
\hline$\bullet$ & $\begin{array}{l}\text { Die hoeveelheid voedsel pas by die } \\
\text { inwoners se eetlus }\end{array}$ & 33 & 100 & 0 & 0 \\
\hline
\end{tabular}

dat daar nie ' $n$ stoel beskikbaar is wat aan al die behoeftes van amulante. gestremdes en stoelgebonde bejaardes voldoen nie, behoort die terapeutiese waarde van 'n stoel besef te word.

Daar word omgesien na die bejaarde se veiligheid aangesien handrelings in gange, brandbestrydingstoerusting en vloerbedekking van nie-glymateriaal in al die tehuise teenwoordig was.

Slegs vier van die tehuise het nagligte in die gange gehad.

Die afwesigheid daarvan kan 'n risiko vir val by bejaardes veroorsaak wanneer hulle in die nag opstaan en in die donker sukkel.

Hystoestelle was slegs in drie $(30 \%)$ tehuise beskikbaar. In teenstelling met die literatuur skram die personeel nie weg van die hystoestelle in die drie tehuise nie (Norton 1970:59).

Die navorser het waargeneem hoe dit aangewend word en personeel het meegedeel dat hulle nie sonder die noodsaaklike hulpmiddel kan werk nie. Volgens die personeel ervaar die bejaardes slegs die eerste paar keer angs, maar vertrou die apparaat indien hulle goed ingelig word en dit herhaaldelik gebruik word. Dit is jammer dat sewe tehuise sonder die hulpmiddel moet klaarkom.

In tabel 1 word aspekte in die struktuur uitgelig wat ' $n$ invloed kan hê op stimulasie en realiteitsoriëntasie van bejaardes. Die leemtes wat uitgewys word benodig ' $n$ verandering van die personeel se ingesteldheid op realiteitsoriëntasie en stimulasie.

Alhoewel dit geblyk het dat van die personeel nie altyd ingestel was om aspekte in die struktuur ten opsigte van stimulasie en realiteitsoriëntasie te bevorder nie was daar verpleegkundiges wat werklik kreatiwiteit openbaar het byvoorbeeld een het ' $n$ eettafel wat oor ' $n$ stoel pas ontwerp en ' $n$ ander verpleegkundige het ' $n$ stortstoel ontwerp.

\section{Proses}

Evaluering van die indivuele inwoners Die verpleegsorg wat aan 45 verswakte bejaardes gelewer word is geobserveer. Uit die rekords is waargeneem dat versorging soms plaasvind sonder dat ' $n$ beraming van die pasiënt gedoen is. Van agt $(17,7 \%)$ bejaardes is geen beraming gedoen nie en die beramings wat wel gedokumenteer was, was onvolledig, want slegs 17 van die 77 items is op meer as $50 \%$ van die vorms aangeteken. Beramings word ook nie dadelik met opname gedoen nie aangesien net een rekord $(2,2 \%)$ binne twee uur na opname voltooi is. Dit het ook geblyk dat beramings net eenmalig gedoen word, dit wil sê opgeloste probleme word nie op die rekord gekanselleer nie en nuwes word nie aangeteken nie. Wat rekordhouding betref was daar net $33(73,3 \%)$ inskrywings op die vorderingsverslag. In die meeste gevalle was daar nie sprake van deurlopende rekordhouding nie. Inskrywings word slegs gemaak "wanneer daar iets buitengewoons gebeur" soos een verpleegkundige dit gestel het, byvoorbeeld wanneer 'n bejaarde geval het of wanneer die geneesheer ' $n$ besoek gebring het. Inskrywings is ook stereotipes byvoorbeeld "toestand onveranderd", "geen nuwe bevele" en "geen klagtes". Die afleiding kan gemaak word dat pasiënte se verpleegprobleme of nooit geidentifiseer is nie en/of die inwoners se response op verpleegsorg om die probleme te verlig of op te los is nie op die rekord aangeteken nie. Slegs in vier $(8,9 \%)$ gevalle is daar in terme van geidentifiseerde probleme geëvalueer en ' $n$ belangrike probleem naamlik afname in vel integriteit as gevolg van edeem (Staab \& Lyles 1989:143) is nooit as ' $n$ probleem raakgesien nie. Die navorser het wel edeem by twaalf bejaardes geidentifiseer.
Die indruk is gekry vanuit waarneming sowel as uit gesprekvoering met die verpleegkundiges dat beraming en probleemidentifisering as ' $n$ bykomende werklas beskou word en dat daar ook ' $n$ gebrek aan insig in die verpleegproses is.

Die meeste aangeleenthede wat met eet verband hou, was positief soos in Tabel 2 aangedui.

Slegs $12(26,7 \%)$ persone is gevoer. Daar is waargeneem dat die personee oor die algemeen poog om die inwoners onafhanklik te laat eet. In sommige gevalle het dit vir die navorser gelyk asof dit bykans onmoontlik is vir ' $n$ bepaalde persoon om self te eet, en tog het hy dit gedoen. Wat eet betref, was dit duidelik dat onafhanklikheid aangemoedig word in teenstelling met bevindinge in die literatuur (Armstrong-Esther et al. 1985:495)

Daar kon meer aandag gegee gewees het aan die posisionering van die bejaardes tydens etenstye. Alhoewel 21 $(63,6 \%)$ gemaklik was het $12(36,4 \%)$ ongemak ervaar. ' $n$ Tafeltjie om op te eet het ontbreek, die persoon se stoel was nie ingeskuif nie of die stoel was te hoog. Kolodny en Malek (1991:23-24) het ook waargeneem dat personeel afhanklike bejaardes met etenstye nie korrek posisioneer nie.

Volgens die navorser moet daar ook tydens evaluering waargeneem word hoe bejaardes gevoer word. By agt $(66,6 \%)$ het personeel nie gesit terwyl hulle 'n pasiënt voer nie wat weer eens met Kolodny en Malek (1991:23-24) se bevindige ooreenstem. Volgens Backstorm et al. (1987:75) is dit wenslik dat slegs een persoon ' $n$ bejaarde gereeld voer. Die navorser het egter waargeneem dat daar nie doelbewus hiervoor beplan word nie. Dit was opvallend dat die inwoners nie tydens etenstye gesels het nie. Hulle het mekaar egter ondersteun, byvoorbeeld deur mekaar se kos fyn te sny of mekaar na die eetsaal te begelei.

Om maaltye in die eetkamer te nuttig het 'n positiewe effek op sosialisering. Slegs $11(24,4 \%)$ persone het in die eetkamer geëet van wie slegs $3(6,7 \%)$ volgens die narvorser se mening onbevoeg was om daar te eet. Ten opsigte van die 31 $(68,9 \%)$ wat nie daar geëet het nie het die navorser opgemerk dat daar nie spesiaal pogings aangewend is om hulle na die eetkamer te neem nie. Daar is uit die staanspoor in die kamer op ' $n$ tafel of skinkbord vir hulie gedek.

Veertien $(31,1 \%)$ was inkontinent van urien en 'n gewoonte opleidingsprogram is net by een $(7,1 \%)$ bejaarde geimplementeer. Daar kan van hierdie bevindinge afgelei word dat weinig aandag aan inkontinensie gegee word, terwyl $45 \%$ tot $75 \%$ van inkontinensie deur verskillende rehabilitatiewe 


\begin{tabular}{|c|c|c|c|c|c|}
\hline \multicolumn{2}{|c|}{ BEDLêEND } & \multicolumn{2}{|c|}{ STOELGEBONDE } & \multicolumn{2}{|c|}{ LOOP MET HULP } \\
\hline $\mathbf{F}$ & $\%$ & $\mathbf{F}$ & $\%$ & $\mathbf{F}$ & $\%$ \\
\hline 15 & 33,3 & 16 & 35,6 & 14 & 31,1 \\
\hline
\end{tabular}

tegnieke beheer kan word (Campbell 1971:147; en Wright 1988:816). Die aspekte wat geëvalueer is met betrekking tot kateter versorging was oor die algemeen goed gedoen.

In twee tehuise het die navorser waargeneem dat ' $n$ verpleegassistent die urien kateter passeer. Volgens die mening van die navorser het dit nie steriel plaasgeving nie. Dit kan 'n groot risiko vir die bejaarde inhou.

Edeem het by $12(26,7 \%)$ van die bejaardes voorgekom en dehidrasie is by drie $(6,7 \%)$ geïdentifiseer. Daar is in geen rekord van hierdie bejaardes ' $n$ inskrywing met betrekking tot edeem en dehidrasie gemaak nie. Dit dui op ernstige versuim van die verpleegkundiges.

Daar is ook goed na die higiëne omgesien. Met die uitsondering van twee bejaardes $(4,4 \%)$ was almal se hare skoon en gekam. Die oorgrote meederheid $36(80 \%)$ se naels was skoon en $33(73,3 \%)$ s'n was ook goed aangesien $42(93,3 \%)$ se monde en tande skoon was. Meer aandag kon egter aan die voete gegee gewees het. Drie $(6,7 \%)$ persone het voetinfeksies gehad, een $(2,2 \%)$ het ingroeitoonnaels gehad en verdikte toonnaels was by 10 $(22,2 \%)$ teenwoordig. Aangesien voetprobleme voorgekom het wat die mobiliteit van die bejaarde kan beïnvloed blyk dit dat daar ' $n$ behoefte is aan ' $n$ voetkundige op ' $n$ konsulterende basis, vir tehuise.

Uit 'n totaal van 554 verswakte bejaardes in die 10 tehuise het vier $(0,72 \%)$ 'n bedseer. Amerikaanse navorsers, Kelly et al. (1991:24) het bevind dat die voorkoms van druksere onder bejaardes in langtermyn fasiliteite varieer van 12 tot $23 \%$. Die lae persentasie wat in die studie verkry is, is prysenswaardig.

In Tabel 3 word die mobaliteit van die inwoners aangedui.

Nie een van die bedlêende en stoelgebonde bejaardes het passiewe oefening ontvang nie. Diep asemhalings- en hoesoefeninge is slegs aan twee $(12,5 \%)$ gegee. Drie $(21,4 \%)$ van dié wat met hulp loop het twee keer per week hulp met oefening ontvang.

Dit is veral die bedlêende bejaardes wat 'n groot behoefte aan oefening het en die negatiewe effek wat ' $n$ totale gebrek aan oefening op hulle het, is dan ook waargeneem, byoabedd kontrakture e $n$ styfheid. Dit blyk dus dat d i e regulasie $w$ a $t$ handel oor bestek van praktyk no. R.1469 van 1987 vir geregistreerde persone ten opsigte van die bevordering van oefening en voorkoming van liggaamsmisvorming nie in tehuise van bejaardes realiseer nie (SARV 1984, R.2598 soos gewysig deur R.260).

Daar kan ook meer aandag aan die tipe skoene wat die bejaarde dra gegee word want ook dit kan mobiliteit beinvloed. Gemakstoele wat 'n swak anatomiese posisie bevorder kan ook behoorlike borskasuitsetting belemmer.

Daar was egter positiewe aspekte, naamlik dat onafhanklikheid aangemoedig word ten opsigte van aantrek, stap na toilet en eetkamer. Die geskikte toerusting, byvoorbeeld wandelstokke en looprame wat goed aangewend was om ambulansie te bevorder is ook ' $n$ pluspunt. Om oefening te gee aan bejaardes kan maklik agterweë gelaat word omdat dit nie 'n noodsaaklikheid soos voeding, die uitdeel van geneesmiddels en die hantering van uitskeidingsbehoeftes is nie. Die bejaarde ervaar ook nie dadelik die effek van die gebrek aan oefening nie. Die langtermyn effek daarvan is egter nadelig want dit het gesondheidsen finansiële implikasies tot gevolg (Selikson et al. 1988:708).

Daar is goed in die gemak en slaap behoeftes van die inwoners voorsien. Vyf en dertig $(77,8 \%)$ van hulle het aan die navorser meegedeel dat wanneer hulle pyn het die verpleegpersoneel voldoende aandag daaraan skenk.

Tien $(22,2 \%)$ het gevoel dat hulle nie voldoende aandag kry wanneer hulle klagtes van pyn het nie. Volgens Dreyfuss (1988:36) moet klagtes van pyn sorgvuldig geëvalueer word. Ander faktore soos depressie, verveeldheid en eensaamheid (Fordyce 1978:60) kan dalk ' $n$ rol speel by dié wat gekla het. Genoemde faktore kan 'n rede wees waarom daar nie pynpille voorsien is nie. Verpleegpersoneel behoort dan nie die "pyn" te ignoreer nie, maar aandag aan die depressie, verveeldheid en eensaamheid te gee. ' $n$ Beramingsinstrument vir pyn kan ook aangewend word. ( Herr \& Mobily 1991:16).

\section{Aanbevelings}

\section{Struktuur}

- Met die beplanning van nuwe tehuise en wanneer strukturele verbeterings aan bestaande tehuise aangebring word behoort ' $n$ verpleegkundige met kennis van geriatriese verpleegsorg op die beplanningskomitee te dien.

- Meer aandag moet aan die spesifieke behoeftes van verwarde bejaardes in die struktuur gegee word.

- Die voorsiening van die volgende items word sterk aanbeveel: hystoestelle, verhoogde toiletsitplekke of ' $n$ verstelbare toiletsitplek, voldoende stoele en plastiek tandebakkies.

- Maatreëls wat getref kan word om realiteitsoriëntasie te bevorder soos byvoorbeeld horlosies en kalenders kan aangebring word.

\section{Proses}

'n Akkurate en omvattende beraming is die grondslag van hoë kwaliteit versorging in enige sorgsentrum (Eliopoulus 1990:24) en daar word aanbeveel dat hierdie taak dringende aandag geniet. Rekordhouding moet

Tabel 2 : Mobiliteit van inwoners $(N=45)$

$\begin{array}{lll}\text { TEHUISE INRIGTING } & \begin{array}{c}\text { EENHEDE VIR } \\ \text { VESWAKTE } \\ \text { BEJAARDES }\end{array}\end{array}$

66,6
65,6
72,3
66,1

56,9
81,5
60
70,7
71,8
83

71,1
50
65,3
61,5
$(01+02)$
51,9
80,7
52,9
57,8
67,3
73

56,6

56,3

64,9

59,7

43,5

62,14

50,4

71,34

66,99

68,4
69,4
X 
opgeskerp word.

Ten einde die lewenskwaliteit van bejaardes te bevorder word aanbeveel dat hulle die nodige stimulasie en voldoende onstpanningsgeleenthede sal ontvang.

- Noukeurige rekordhouding van inkontinensie verpleegtussentredes en die evaluering van pasiënt response op die tussentrede sal inkontinensiebeheer bevorder.

- Die waarde van oefening as voorkomingsmaatreël teen kontrakture en die voordele wat dit vir die algehele welsyn van bejaades inhou moet besef word en pogings moet aangewend word sodat al die verswakte bejaardes voldoende oefeninge sowel as asemhalings- en hoesoefeninge ontvang.

- Daaglikse roetine behoort speling vir variansie toe te laat.

- $\quad$ Groter pogings kan aangewend word om soveel as moontlik van die inwoners in die eetkamer te laat eet.

- Weens die noodsaaklikheid van voldoende voginname behoort in verskeidenheid dranke meer dikwels aangebied te word.

- Vier bejaardes het ' $n$ wond gehad en slegs een is volgens aseptiese tegniek versorg. Daar is tydens die studie waargeneem dat die verpleegassistente die wonde versorg. Aangesien dit blyk dat daar nie baie wonde voorkom nie (in die huidige studie minder as $10 \%$ ) word aanbeveel dat die verpleegkundige tyd maak om dit self te doen.

- In twee tehuise is waargeneem dat verpleegassistente die urienkateters passeer. Die navorser het opgemerk dat dit nie steriel gedoen word nie. Soos by die versorging van wonde word aanbeveel dat die verpleegkundige ook hierdie belangrike taak verrig.

\section{Resultaat}

- Instrument : Kwaliteit van die verpleegsorg van verswakte bejaardes

Bogenoemde instrument was maklik om te gebruik en daar word aanbeveel dat die personeel van elke tehuis dit gereeld, byvoorbeeld ses maandeliks toepas om die stand van sake in hul eie tehuis te bepaal. Dit is by die SA Verpleegstersvereniging Hoofkatnoor beskikbaar.

Die Departement van Gesondheidsdienste en Welsyn kan dit ook met vrug tydens hulle inspeksies gebruik. Doelwitte vir die verbetering van spesifieke leemtes in verpleegsorg kan na aanleiding van die evaluering gestel word wat by die volgende inspeksie geëvalueer kan word. Redes vir onaanvaarbare standaarde van sorg kan bepaal word en toepaslike aandag kan daaraan gegee word.

\section{Slot}

Die kwaliteit van verpleegsorg in al die inrigtings word in Tabel 4 opgesom. Die gemiddelde persentasie vir die inrigtings (struktuur) was $69,4 \%$, vir die eenhede vir verswakte bejaardes $63,2 \%$ en dié van die inwoners $60 \%$. Dit blyk dus dat die versorging van die bejaardes meer aandag nodig het as die struktuur en die eenhede van die verswakte bejaardes. Die gemiddelde persentasies vir sorg aan inwoners was bo die gemiddelde $(60 \%)$ met Tehuis 8 wat oor die algemeen die beste gevaar het met ' $n$ gemiddeld van $71,34 \%$. Tehuis 5 het buitengewoon swak gevaar met $43,5 \%$. Voorbeelde van goeie en minder goeie verpleegsorg het dus voorgekom.

Uit hierdie navorsing het dit geblyk dat daar grotendeels net op die fisieke gekonsentreer word. ' $n$ Benadering van bewaarsorg word dus gevog omdat aspekte ten opsigte van realiteitsoriëntasie en stimulasie nie voldoende aandag geniet nie. 'n Gewoonteopleidingsprogram was slegs by een bejaarde geiimplementeer en bejaardes kry ook nie oefening nie. Hierdie bevinding is in ooreenstemming met die literatuur (Castledine 1982:19; en Helelr et al. 1984:23). Ten spyte hiervan is die kwaliteit van versorging redelik ( $X=60 \%$ ). Volgens die akademiese kwalifikasies van die personeel het $61,2 \%$ nie oor ' $n$ matrieksertifikaat beskik nie en slegs ses $(4,5)$ het ' $n$ graad in Verpleegkunde. Die bewaarsorg benadering kan moontlik hieraan toegeskryf word. 'n Rehabilitatiewe benadering noodsaak innoverende denke en daarvoor is persone met ' $n$ hoër opleidingsvlak nodig. ' $n$ Bejaarde kan egter nie volledig as mens funksioneer nie tensy daar ook aandag aan sy psigiese en sosiale beheoftes gegee word nie. ' $n$ Benadering van "add life to years" vereis dat daar meer op rehabilitasie gekonsentreer word. 


\section{Verwysing}

ALLEN, C.I. \& TURNER, P.S. (1991) : The effect of an intervention programme on interactions on a continuing care ward for older people, Journal of Advanced Nursing, 16(10):1172-1177.

ARMSTRONG-ESTHER, C.A., SANDILANDS, M.C. \& BROWN, K.D. (1985): Present and future care of the elderly, Journal of Advanced Nursing, 10(4):491-496.

BACHMANN, G.A. \& GRILL, J. (1987): Exercise in the postmenopausal woman, Geriatrics, 42(1):75-81.

BACKSTROM, A., NORBERG, A. \& NORBERG, B. (1987): Feeding difficulties in long-stay patients at nursing homes. Caregiver turnover and caregivers' assessments of duration and difficulty of assisted feeding and amount of food received by the patient, International Journal of Nursing, 24(1):26-76.

BURNS, N. \& GOVE, S.K. (1987): The practice of nursing research : Conduct, critique and utilization. Internationl Edition, Philidelphia : W.B. Saunders.

CAMPBELL, M.E. (1971): Study of the attitudes of nursing personnel toward the geraitric patient, Nursing Research, 20(2):147-151.

CASTLEDINE, G. (1982) : Sorry lhaven;t got time, Nursing Mirror, 155(11):17-20.

COHN, M.D., HORGAS, A.L. \& MARSISKE, M. (1990): Behavior management training for nurse aides: Is it effective, Journal of Gerontological Nursing, 16(11):21-24.

CONNEL, A.M. (1988): Quality or quanity? Senior News, 21(3):5.

COX, C.L., KAESER, L., MONTGOMERY, A.C. \& MARION, L.H. (1991): Quality of life : Nursing care - an experimental trial in long-term care. Journal of Gerontological Nursing. 17(4):6-1.

DEPARTEMENT VAN GESONDHEIDSDIENSTE EN WELSYN - NAVORSING EN INLIGTING. (1987): Handleiding oor die navorsing van bejaardes in tehuise. 3de uitgawe. Department van Gesondhieds- dienste en Welsyn. Administrasie : Volksraad, Pretoria.

DREYFUSS, J.K. (1988): Depression assessment and interventions in the medically ill frail elderly, Journal of Gerontological Nursing, 14(9):27-36.

ECKLEY, S.C.A. (1989) : Tehuise vir bejaardes, Senior Nuus, 22(2):1-2.
ELIOPOULOS, C. (1983): Nurse staffing in long-term care facilities: The case against a high ratio of RN, Journal of Nursing Administration, 10(10):29-31.

FORDYCE, W.E. (1978): Evaluating and managing chronic pain, Geriatrics 33(1):59-62.

GLAJCHEN, D. (1989): Geriatric imperative, South African Medical Journal, 76(4):160-163.

HELLER, B.R., BAUSELL, F.R.B. \& NIHOS, M. (1984): Nurses' perceptions of rehabilitatio potential of instittionalized aged, Journal of Gerontological Nursing, 17(4):238-239.

HERR, K.A. \& MOBILY, P.R. (1991): Complexities of pain assessment in the elderly : Clinical considerations, Journal of Gerontological Nursing, 17(4):12-17.

HOWES, F. (1989): Bejaardesorgbeleid: 'n Herbeskouing, Maatskaplike Werk/ Sosial Work, 25(4):238-239.

HUNT, N.B. \& UYS, L.R. (1990): The quality of nursing care of the frail aged in selected institutions in Eastern Cape and Natal, Cutrationis, 13(9):24-29.

KOLODNY, V. \& MALEK, A.M. (1991): latrogenesis in the elderly. Impaired skin integrity, Journal of Gerontological Nursing, 17(9):24-29.

LAMPMAN, R.M. (1987): Evaluating and prescribing exercise for elderly patients, Geriatrics, 42(8):63-76.

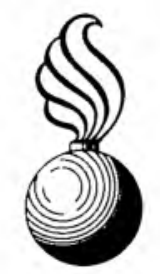

